\title{
INOVASI BIROKRASI PELAYANAN PUBLIK BIDANG SOSIAL TENAGA KERJA DAN TRANSMIGRASI DI KABUPATEN KUDUS
}

\author{
Aufarul Marom ${ }^{1}$
}

\begin{abstract}
One thing that can be felt directly by the people of the presence of government and bureaucracy is a public service. Through this public service to the community will be able to assess the how big is the quality of service that has been provided by the institutions of public services to the community as well as to the level where people feel satisfied with the existing services. Public complaints against the lack of quality of service is one indicator that shows the inadequacy of the services provided by the bureaucratic apparatus. Demands and needs of the community is a challenge for bureaucracy to be able to provide the best service and to be able to perform its function properly. To that end, bureaucratic institutions need to implement a service improvement strategy that responds to the needs of people who wish to improve the quality of service. Based on the results of the study showed that the social field of manpower and transmigration in Kudus Regency has two very popular service innovation and seeded. The first innovation is innovation that is the home of surgical services for Kudus residents and citizens of the disadvantaged have the opportunity to receive services such as house surgeon with the requirements that have been set. The second innovation in the form of a death benefit up to one million rupiah for the Kudus citizens who are entitled to obtain it. The conclusion of the research showed that the Public Service Innovation in Dinsosnakertrans Kudus Regency has been done with a Yellow Card service opportunities through on-line. Social Assistance Home Surgery is often still experiencing problems because of incomplete to the terms and conditions required for the maintenance of such assistance. Social Assistance Benefit Death still constrained quite a long time to reduce the assistance because disbursement procedure that is long enough
\end{abstract}

Key words : Innovation, Bureaucracy, Service, Dinsosnakertrans

\section{PENDAHULUAN}

Satu hal yang dapat dirasakan secara langsung oleh masyarakat dari keberadaan pemerintah dan birokrasi adalah pelayanan publik. Melalui pelayanan publik inilah masyarakat akan bisa menilai sampai seberapa besarkah kualitas pelayanan yang telah diberikan oleh lembaga-lembaga pelayanan publik kepada

\footnotetext{
${ }^{1}$ Staf Pengajar Program Studi S1 Administrasi Publik FISIP - Undip
} 
masyarakat serta sampai pada level mana masyarakat merasa terpuaskan dengan pelayanan yang ada.

Pelayanan publik menjadi isu kebijakan yang semakin strategis karena perbaikan pelayanan publik di Indonesia terkesan "berjalan di tempat" sedangkan implikasinya sangatlah luas dalam kehidupan ekonomi, politik, sosial budaya dan lain-lain. Pelayanan publik menjadi fokus karena berhadapan dan bersentuhan langsung dengan masyarakat seperti halnya pada pelayanan perijinan, pelayanan kesehatan, pelayanan pendidikan dan bentuk pelayanan lainnya.

Pelayanan publik merupakan layanan yang diselenggarakan oleh pemerintah, baik pemerintah pusat, provinsi maupun daerah menurut level dan jenis pelayanan yang diberikan. Hal ini sesuai dengan apa yang disebutkan dalam Keputusan Menpan No. 63/Kep/M.PAN/7/2003 dimana penyelenggaraan pelayanan publik merupakan salah satu fungsi utama dalam penyelenggaraan pemerintah yang menjadi kewajiban aparatur pemerintah. Disebutkan juga bahwa pengertian pelayanan publik adalah segala kegiatan pelayanan yang dilaksanakan oleh instansi pemerintah sebagai upaya pemenuhan kebutuhan orang, masyarakat, instansi pemerintah dan badan hukum maupun sebagai pelaksananan ketentuan peraturan perundang-undangan. Tuntutan masyarakat untuk mendapatkan pelayanan publik yang berkualitas, berprosedur jelas, dilaksanakan dengan segera, dan dengan biaya yang pantas, telah terus mengedepan dari waktu ke waktu. Tuntutan ini berkembang seiring dengan peningkatan kesadaran bahwa warga negara dalam kehidupan bernegara bangsa yang demokratis memiliki hak untuk dilayani.

Keluhan masyarakat terhadap kurangnya kualitas pelayanan merupakan salah satu indikator yang menunjukkan belum memadainya pelayanan yang diberikan oleh aparatur birokrasi. Tuntutan dan kebutuhan masyarakat tersebut merupakan tantangan bagi birokrasi untuk dapat memberikan pelayanan yang terbaik serta untuk dapat melaksanakan fungsinya dengan baik. Untuk itu, 
institusi birokrasi perlu menerapkan strategi peningkatan pelayanan yang tanggap terhadap kebutuhan-kebutuhan masyarakat yang menghendaki peningkatan kualitas pelayanan.

Berkembangnya tuntutan dari masyarakat akan pelayanan yang baik memunculkan konsep good governance diartikan sebagai pengelolaan pemerintahan yang baik, Koirudin (2005:160). Fokus analisis atas pelaku good governance terdiri atas, pertama, negara, yang dijabarkan dalam eksekutif, legislatif dan yudikatif serta militer. Kedua, masyarakat sipil, terdiri atas LSM, ormas, media massa, asosiasi berdasarkan profesionalitas, kelompok-kelompok agama dll. Dan ketiga, pasar ekonomi. Ketiga pelaku good governance ini saling berinteraksi dan saling mempengaruhi satu sama lain sesuai dengan kapasitasnya masing-masing.

Tidak hanya berhenti pada konsep Good Governance, Reformasi birokrasi muncul sebagai upaya menyeluruh dan komprehensif atas perbaikan kualitas pelayanan publik (Perpres No 81 Tahun 2010 tentang Grand Design Reformasi Birokrasi 2010-2025). Reformasi Birokrasi pada dasarnya adalah upaya untuk melakukan perbaikan kinerja birokrasi, dengan meningkatkan kualitas regulasi, meningkatkan efisiensi, efektivitas dan akuntabilitas seluruh aspek penyelenggaraan pemerintahan dan meningkatkan kualitas pelayanan kepada masyarakat, yang pada gilirannya akan meningkatkan kepercayaan masyarakat kepada Pemerintah serta meningkatkan citra Indonesia di mata internasional.

Pengertian ini tampaknya sangat mudah untuk dipahami, tetapi di dalamnya mengandung kompleksitas proses perubahan yang rumit. Perubahan tidak hanya sekedar perubahan terhadap struktur organisasi, tetapi juga menyangkut berbagai proses penyelenggaraan pemerintahan di seluruh daerah; harmonisasi dan streamlining berbagai regulasi, perubahan mendorong pada sistem manajemen SDM yang mampu mendorong kinerja organisasi; dan perubahan pada sistem pengawasan dan akuntabilitas yang mampu mendorong penyelenggaraan pemerintahan yang bersih dan bebas KKN. Langkah-langkah 
perubahan tersebut diharapkan dapat membawa dampak positif terhadap upaya peningkatan kualitas pelayanan publik serta perubahan pola pikir dan budaya kerja aparatur.

Dalam Perpres No 81 Tahun 2010 tentang Grand Design Reformasi Birokrasi 2010-2025 yang kemudian diturunkan ke dalam Permen PAN dan RB No 20 Tahun 2010 tentang Road Map Reformasi Birokrasi 2010-2014 yang menekankan pada arah kebijakan pelaksanaan reformasi birokrasi nasional agar reformasi birokrasi di Kementerian/Lembaga dan Pemerintah Daerah dapat berjalan secara efektif, efisien, terukur, konsisten, terintegrasi, melembaga, dan berkelanjutan.

Kabupaten Kudus sebagai salah satu kabupaten di Wilayah Jawa Tengah memiliki wilayah garapan pelayanan publik dalam berbagai bidang seperti bidang kesehatan, kependudukan dan catatan sispil, perijinan dan layanan satu atap, pendidikan, pariwisata, perdagangan, sosial tenaga kerja dan transmigrasi, lingkungan dan sebagainya. Bidang sosial, tenaga kerja dan transmigrasi juga merupakan salah satu bidang yang sangat penting mengingat banyaknya persoalan yang muncul di bidang tersebut.

Di bidang Sosial menunjukkan banyaknya bencana alam pada tahun 2010 di kabupaten Kudus sebanyak 20 bencana dimana total kerugiannya mencapai 98,83 juta rupiah, dengan jumlah korban luka-luka sebanyak 3 orang. Sedangkan banyaknya penderita cacat di kabupaten Kudus sebanyak 1.844 orang, sebagian besar tuna raga/ tubuh dan tuna netra. Tercatat juga jumlah anak terlantar ada sebanyak 25 orang. Dibidang Tenaga Kerja berdasarkan data dari Dinas Tenaga Kerja dan Transmigrasi kabupaten Kudus terdapat sebanyak 113.494 orang pekerja yang tersebar di 1.057 perusahaan, dimana sebagian besar adalah pekerja perempuan sebesar 72,67 persen. Dari data juga terlihat bahwa pencari kerja lebih banyak bila dibandingkan dengan lapangan usaha yang tersedia. Banyaknya pencari kerja pada tahun 2010 sebanyak 11.086 orang 
sedangkan permintaan/ kebutuhan tenaga kerja hanya sebesar 3.419 orang. Hal ini menyebabkan masih banyak para pencari kerja yang belum bisa ditempatkan.

Penelitian ini memiliki tujuan sebagai berikut : Untuk mengetahui inovasi apa saja yang dilukan di bidang pelayanan sosial, tenaga kerja dan transmigrasi di Kabupaten Kudus, Untuk menganalisis penyelenggaraan dan kinerja pelayanan publik di bidang sosial, tenaga kerja dan transmigrasi di Kabupaten Kudus, Untuk merumuskan strategi reformasi peningkatan pelayanan publik di bidang sosial tenaga kerja dan transmigrasi di Kabupaten Kudus, Untuk menemukan faktorfaktor apa saja yang mendorong dan menghambat dalam penyelenggaraan inovasi birokrasi pelayanan publik di bidang sosial tenaga kerja dan transmigrasi di Kabupaten Kudus

Pelayanan publik dengan kualitas tinggi membutuhkan pemerintahan yang kuat, untuk mampu menjalankan fungsi pemerintahan dengan efektif (Ohmae, 2005). Pemerintahan yang kuat berperan sebagai fasilitator yang mengarahkan, mengelola pemerintahan yang memampukan/ memberdayakan stakeholder dengan semangat kewirausahaan (Osborne,Gaebler, 1993). Kualitas pelayanan publik yang rendah membuka peluang penyelewengan kekuasaan publik yang menyebabkan biaya transaksi bisnis menjadi tinggi sehingga daya saing rendah.

Perubahan paradigma pelayanan publik bergerak dari Old Public Administration ke New Public Service (NPS). Pada Old Public Administration fokus pemerintah pada pelayanan publik secara langsung melalui badan-badan pemerintah. Program publik dilaksanakan melalui organisasi hirarkis, dengan manajer yang menjalankan kontrol dari puncak organisasi. Organisasi publik beroperasi sebagai sistem tertutup, sehingga partisipasi warga negara terbatas. Kebijakan publik dan administrasi menyangkut perumusan dan implementasi kebijakan dengan penentuan tujuan yang dirumuskan secara politis dan tunggal (Dernhart dan Dernhart, 2004).

Kemudian muncul New Public Management (NPM) yang mencoba menggunakan pendekatan bisnis di sektor publik. Berorientasi pada mekanisme 
pasar dimana hubungan antara organisasi publik dan customer dipahami sebagaimana transaksi yang terjadi di pasar. Konsep "steer not row" artinya birokrat/ PNS tidak mesti menjalankan sendiri tugas pelayanan publik, apabila dimungkinkan fungsi itu dapat dilimpahkan ke pihak lain melalui sistem kontrak atau swastanisasi.

Hingga kritik terhadap NPM yang memunculkan NPS (New Public Service), dimana paradigma NPS memperlakukan publik pengguna layanan publik sebagai warga negara (citizen) bukan sebagai pelanggan (customer). Administrasi negara tidak sekedar bagaimana memuaskan pelanggan tapi juga bagaimana memberikan hak warga negara dalam mendapatkan pelayanan publik.

Selanjutnya perubahan dari paradigma New Public Management menjadi New Public Service dapat digambarkan sebagaimana berikut :

\section{Gambar 1}

\section{Perubahan Paradigma NPM menjadi NPS}
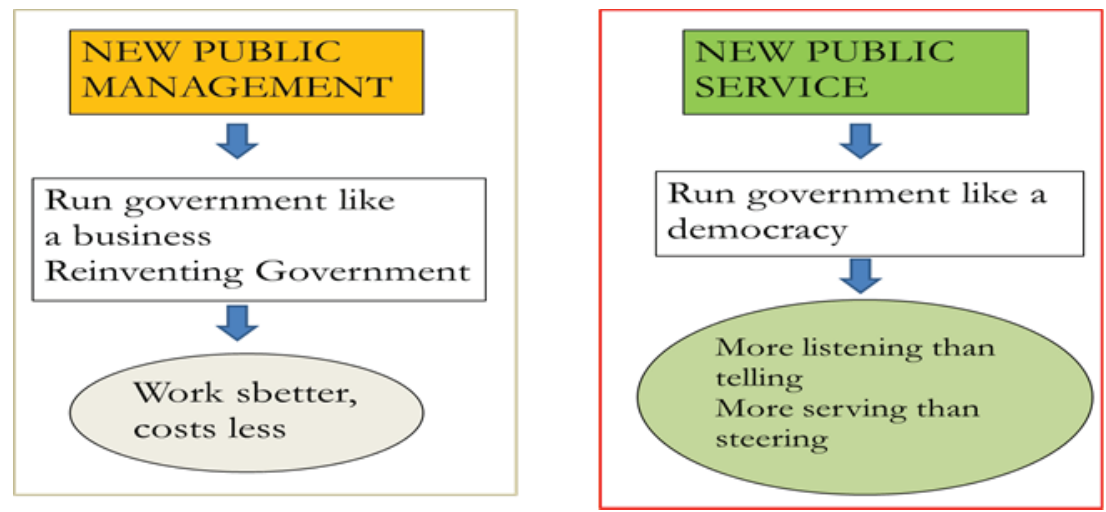

Pelayanan publik pada dasarnya menyangkut aspek kehidupan masyarakat yang sangat luas. Dalam kehidupan bernegara, maka pemerintah memiliki fungsi memberikan berbagai pelayanan publik yang diperlukan oleh masyarakat, mulai dari pelayanan dalam bentuk pengaturan atau pun pelayanan-pelayanan lain dalam rangka memenuhi kebutuhan masyarakat.

Secara teoritis tujuan pelayanan publik adalah memuaskan masyarakat. Untuk dapat memberikan pelayanan yang memuaskan bagi masyarakat, penyelenggaraan pelayanan harus memenuhi asas- asas pelayanan sebagai 
berikut: (Keputusan MENPAN No.63 tahun 2003) : Transparansi, bersifat terbuka, mudah dan dapat diakses oleh semua pihak yang membutuhkan dan disediakan secara memadai serta mudah dimengerti; Akuntabilitas, dapat dipertanggungjawabkan sesuai dengan ketentuan peraturan perundangundangan; Kondisional, sesuai dengan kondisi dan kemampuan pemberi dan penerima layanan dengan tetap berpegang pada prinsip efisiensi dan efektifitas; Partisipatif, mendorong peran serta masyarakat dalam penyelenggaran pelayanan publik dengan memperhatikan aspirasi, kebutuhan dan harapan masyarakat; Kesamaan hak, tidak diskriminatif dalam arti tidak membedakan suku, agama, golongan, ras, gender dan standart ekonomi; Keseimbangan hak dan kewajiban, pemberi dan penerima pelayanan publik harus memenuhi hak dan kewajiban masing- masing pihak.

Reformasi birokrasi dalam penyelenggaraan pemerintahan yang sedang bergulir saat ini menempatkan pelayanan publik sebagai bagian dari agenda nasional. Reformasi birokrasi menjadi bagian penting ketika dikaitkan dengan pelayanan yang efektif dan efisien kepada masyarakat. Makna ini lebih jelas ketika mengkaitkannya dengan misi aparat birokrasi yang bertujuan memberikan pelayanan sebaik-baiknya kepada masyarakat, dengan meningkatkan kualitas sumber daya manusia, sehingga bisa memberikan kesejahteraan dan rasa keadilan pada masyarakat banyak. Kata Reformasi Birokrasi sampai saat ini masih menjadi idola yang didambakan perwujudannya oleh sebagian besar masyarakat Indonesia yang diarahkan pada terwujudnya efisiensi, efektivitas, dan clean government. Reformasi ini diarahkan pada perubahan masyarakat yang termasuk didalamnya masyarakat birokrasi, dalam pengertian perubahan ke arah kemajuan.

Reformasi pelayanan publik pada dasarnya adalah perubahan fundamental dalam penyelenggaraan pelayanan publik yang meliputi banyak hal, tidak hanya soal tehnis pelayanan saja, tetapi perubahan mendasar yang mampu merubbahan peilaku dan pola piki penyelenggara layanan untuk lebih 
berorientasi kepada perubahan dalam kerangka pencpaian tujuan dengan lebih baik, lebih berkualitas dan leih bermartabbat dan berhaka.

Oleh sebab itu, yang paling mendesak untuk direformasi dalam kaitannya antara pelayanan publik dan good governance adalah:

a. Perubahan mindset perilaku birokrasi politik dari budaya penguasa menjadi budaya pelayanan.

b. Perubahan prosedur pelayanan dan misi melayani, dari mengendalikan perilaku menjadi mempermudah warga memperoleh layanan.

c. Perubahan struktur organisasi menjadi struktur yang mendukung perbaikan kinerja organisasi.

Memimpin sebuah perubahan memang tidak mudah. Banyak halangan yang harus dilalui tidak hanya internal birokrasi yang menghambat, tetapi juga dinamika masyarakat sering harus dipertimbangkan dalam proses perubahan. Proses perubahan yang berangkat dari satu situasi nasional menuju kearah situasi nasional yang lebih baik dan lebih berharkat merupakan mandat yang harus diwujudkan oleh setiap penyelenggara negara. Birokrasi penyelenggara negara dan penyelenggara pelayanan kebutuhan masyarakat berkewajiban untuk mewujudkan proses pemenuhan kebutuhamn masyarakat sesuai Undang undang Pelayana Publik RI No 25 tahun 2009. Dalam kerangka inilah birokrasi penyelenggara pelayanan publik harus mampu mereformasi diri dan menciptakan inovasi baru dalam penyelenggaraan pelayaan publik. Pembangunan nasional dengan birokrasi pemerintah sebagai penopang dan penyelenggara pelayanan publik mutlak membutukan kemampuan birokrasi yang handal dalam mencipta dan merancang kebijakan dan program-program pelayanan yang inovatif. Konsep inovatif ini terkait dengan kemampuan bersaing (compettitif advantage) dalam menjaga keberlangsungan hidup organisasi, dan inti inovasi adalah perubahan menuju hal-hal baru (Muluk dan Abdullah, 2010).

Inovasi adalah kreasi yang berproses mencipta cara-cara baru, ide-ide baru, dan metode baru merupakan oksigen, yang harus terus mengalir demi 
keberlangsungan organisasi birokrasi dalam mengembangkan fungsi pelayanan pemenuhan kebutuhan masyarakat. Inovasi adalah nafas yang terus mengalir melahirkan ide-ide kreatif. Ide-ide kreatif yang tercipta disemai dan dikembangkan secara terus menerus demi terpenuhinya pemenuhan kebutuhan publik dalam mewujudkan kehidupan masyarakat penuh hasrat, harkat dan martabat. Inovasi sebagai kreasi dalam penyelenggaran pelayanan publik merupakan pengembangan nyata dalam mewujudkan efisiensi, efektifitas, dan kualitas hasil penyelenggaraan pelayanan publik. Inovasi adalah kraesi mencipta cara baru, metode baru atau kombinasi dari cara-cara yang sudah ada, sehingga tercipta cara baru, pemenuhan produk baru, penemuan jasa atau ide dalam proses yang baru. Bagi birokrasi penyelenggara pelayanan publik tujuan akhir dari birokrasi adalah kepercayaan masyarakat. Tipologi inovasi sektor publik adalah : A new or improved service, Proces innovation Administrative innovation, System innovation, Conceptual innovation (Halvorsen dalam LAN, 2013)

Inovasi dalam proses penyelenggaraan pelayanan publik pada birokrasi pemerintah terlahir karena didorong adanya motivasi-motivasi tertentu yaitu: carrier, idealism, power, self fulfilment, money (salary), prestige, professional recognition, dan potential for spin-off bussiness (Mile dan Roste dalam LAN, 2013). Motivasi-motivasi tertsebut pada tataran individu, sedangkan pada tararan organisasi motivasi itu tercipta untuk the propagation of policy, idea or rationality, increase funding, problem solving (in order to reach objective), more staff dan public relation.

Penerapan ide-ide baru dan gagasan cemerlang dalam penyelenggaraan pelayanan publik dimaksudkan untuk menciptakan pelayanan publik yang lebih baik, lebih bermakna, memiliki nilai tambah baik sebagai individu penyelenggara pelayanan dan dalam tataran manajemen organisasi yang lebih luas. Inovasi dalam penyelenggaran pelayanan publik yang bersumber dari motivasi diri dan organisasi dimaksudkan untuk pemenuhan kebutuhan publik juga dimaksudkan 
untuk menjaga eksistensi dan menghadapi dinamika lingkungan internal dan eksternal.

Sedarmayanti (2009:231) menyatakan bahwa inovasi meliputi penciptaan sesuatu yang tidak ada saat ini dan dapat berupa penciptaan kecil atau sesuatu yang monumental. Inovasi sukses memiliki lima karakteristik berikut: Cukup baru bagi pasar; Berdasarkan teknologi yang telah diteliti dan dites; Menghemat uang pengguna inovasi; Memenuhi kebutuhan pelanggan; Mendukung praktek yang ada.

Enam faktor ide menaruh perhatian terhadap bagaimana ide inovasi diawali, yaitu : Mendeteksi kebutuhan : aktif mencari jawaban terhadap masalah yang diketahui; Mendeteksi solusi : menemukan cara baru menggunakan teknologi yang ada; Penemuan mental : hal yang diimpikan di kepala dengan sedikit acuan terhadap dunia luar; Peristiwa acak : saat tidak disengaja ketika inovator menemukan sesuatu yang mereka tidak cari tapi segera mengenali pentingnya hal tersebut; Penelitian pasar: teknik penelitian pasar tradisional untuk menemukan berbagai ide; Mengikuti tren : mengikuti tren demografis dan tren meluas lainnya serta berusaha mengembangkan ide yang mungkin relevan dan berguna

\section{METODE PENELITIAN}

Tipe penelitian yang digunakan peneliti adalah tipe penelitian deskriptif, yaitu untuk mendiskripsikan dan menganalisis penyelenggaraan pelayanan publik untuk kemudian merumuskan strategi reformasi peningkatan pelayanan publik bidang sosial tenaga kerja dan transmigrasi di Kabupaten Kudus. Peneliian ini memfokuskan pada kajian Pelayann Publik dan upaya-upaya perubahan mendasar dan merumuskan strategi dalam peningkatan kinerja pelayanan publik bidang sosial tenaga kerja dan transmigrasi

Data yang digali dari lapangan dengan melalui teknik-teknik pengumpulannya sebagai berikut : Wawancara mendalam (indepth interview) dilakukan untuk menggali data yang berasal dari narasumber. Pengumpulan data 
dengan membuat daftar pertanyaan/ interviw guide kepada informan yang terkait pelaksanaan pelayanan publik bidang sosial, tenaga kerja dan transmigrasi di Kabupaten Kudus; Observasi dilakukan terhadap fenomena yang bisa ditemukan di lapangan yang berkaitan dengan sosial tenaga kerja dan tarnsmigrasi di Kabupaten Kudus; Pencarian literatur ataupun dokumen juga akan dilakukan untuk mendukung data agar dapat memberikan penjelasan yang lebih gamblang terhadap fenomena yang terjadi.

Teknik analisis data secara kualitatif deskriptif dilakukan berdasarkan data yang berhasil diperoleh dari hasil wawancara yang mendalam (depth interview) yang telah dilakukan terhadap para narasumber. Teknis analisis ini melalui langkah-langkah sebagai berikut (1) Reduksi Data yakni mengeliminasi data yang kurang relevan, menyusun abstraksi data dan satuan-satuan data (2) Kategorisasi, data digolong-golongkan sesuai dengan kategorinya (3) Menyusun hubungan antar kategori, satu kategori data dibanding dengan kategori lainnya untuk melihat hubungan antar kategori, untuk selanjutnya diinterpretasi maknamakna setiap hubungan dan (4) Interpretasi dan Kesimpulan, hasil interpretasi hubungan antar kategori selanjutnya dicari makna sebagai kesimpulan (Miles and Huberman, 1992)

\section{HASIL PENELITIAN}

Bidang pelayanan kartu kuning, dengan adanya bantuan tenaga kontrak sangat terbantu. Pelayanan Kartu Kuning sudah dengan menggunakan cara on line. Hambatan yang dirasakan adalah bahwa di Dinsosnakertrans Kabupaten Kudus adalah masih kurangnya SDM yang menangani. Selama ini sudah banyak tenaga PNS yang pensiun tetapi belum ada rekrutmen tenaga yang baru sehingga perlu tambahan PNS yang baru. Akan tetapi dengan adanya kebijakan tenaga kontrak hal ini sangat membantu.

Mereka yang sedang mengurus Kartu Kuning adalah mereka yang terdaftar di Dinsosnakertrans sebagai tenaga kerja yang sedang mencari peluang kerja di bursa atau pasar kerja yang disebut sebagai pencari kerja. Data pencari kerja di 
Kabupaten Kudus selama 7 tahun terakhir menunjukkan angka penurunan yang signifikan sebagaimana tersaji dalam Tabel 1 . berikut :

\section{Tabel 1}

\section{Jumlah Pencari Kerja yang Terdaftar di Dinsosnakertrans}

\begin{tabular}{|l|l|r|r|r|}
\hline No & Tahun & Laki-laki & Perempuan & Jumlah \\
\hline 1 & Tahun 2008 & 5.664 & 5.981 & 11.645 \\
\hline 2 & Tahun 2009 & 5.788 & 5.790 & 11.578 \\
\hline 3 & Tahun 2010 & 5.106 & 5.980 & 11.086 \\
\hline 4 & Tahun 2011 & 4.423 & 5.127 & 9.550 \\
\hline 5 & Tahun 2012 & 4.248 & 5.005 & 9.253 \\
\hline 6 & Tahun 2013 & 3.713 & 4.667 & 8.380 \\
\hline 7 & Tahun 2014 & 2.577 & 2.949 & 5.526 \\
\hline
\end{tabular}

Sumber : Dinsosnakertrans Kabupaten Kudus

Tabel 1. menunjukkan penurunan yang sangat signifikan terhadap Pencari Kerja di Kabupaten Kudus selama 7 tahun terakhir. Pencari kerja sejumlah 11.645 orang pada tahun 2008 turun menjadi 11.578 dalam tahun 2009, turun menjadi 9.550 dalam tahun 2011, bahkan tinggal menjadi 5.526 orang dalam tahun 2014. Gejala penurunan ini tentunya menggembirakan karena berarti bahwa tenaga kerja yang ada sudah terserap dalam pasar kerja. Tabel tersebut juga menunjukkan bahwa selama tujuh tahun tersebut jumlah tenaga kerja wanita yang mencari kerja selalu lebih banyak bila dibandingkan dengan tenaga kerja laki-laki.

Dalam bidang inovasi pelayanan ada dua bidang yang sangat populer yakni pelayanan Bedah Rumah dan Santunan Kematian

\section{Inovasi Pelayanan Bedah Rumah}

Bagi penduduk dan warga Kudus yang kurang mampu memiliki kesempatan untuk memperoleh pelayanan berupa bedah rumah dengan persyaratan yang sudah diatur dalam pelaksanaannya. Berikut adalah kriteria dan persyaratan pengajuan usulan/permohonan Bansos Rehabilitasi Sosial Daerah Kumuh untuk Bedah Rumah Kabupaten Kudus :

a. KELUARGA BERUMAH TIDAK LAYAK HUNI ( KBTLH ) : Keluarga yang kondisi rumahnya dan lingkungannya tidak memenuhi persyaratan yang layak untuk tempat tinggal, baik secara fisik, kesehatan maupun sosial. 
b. KONDISI RUMAH : Luas lantai berkapita kota $<4 \mathrm{M}^{2}$, desa $<10 \mathrm{M}^{2}$; Sumber air tidak sehat, akses memperoleh air bersih terbatas Tidak mempunyai akses MCK; Bahan bangunan tidak permanen atau atap / dinding dari bambu, rumbia,papan kayu yang sudah rapuh; Tidak memiliki pencahayaan matahari dan ventilasi udara; Tidak memiliki pembagian ruangan; Lantai dari tanah dan rumah lembab atau pengap; Letak rumah tidak teratur dan berdempetan; Kondisi rusak; Status Tanah dan rumah milik sendiri dibuktikan dengan Fc.Sertifikat tanah/Leter D/Leter C/Surat Keterangan Kades/Lurah yang menyatakan Tanah dan rumah milik sendiri

c. KONDISI LINGKUNGAN : Lingkungan kumuh dan becek; Saluran pembuangan air tidak memenuhi standart; Jalan setapak tidak teratur

d. KONDISI KELUARGA : Keluarga miskin berpenghasilan di bawah Upah Minimum Kabupaten (UMK); Kesadaran untuk ikut serta memiliki dan memelihara lingkungan pada umumnya rendah (ikut bersih kampung, ikut kerja bhakti,membuang sampah sembarangan di sungai)

e. PERSYARATAN PENGAJUAN USULAN BEDAH RUMAH : Mengajukan proposal permohonan bantuan bedah rumah kepada Bupati Kudus dengan tembusan Kepala Dinas Sosial Tenaga Kerja dan Trasmigrasi dan Kepala DPPKD Kabupaten Kudus; Surat permohonan bantuan bedah rumah ditandatangani oleh Pemohon, diketahui oleh Kepala Desa/Lurah dan Camat; Dilampiri : Rencana Anggaran Biaya (RAB ) Pembangunan Bedah rumah; Foto Copy KTP dan KK yang masih berlaku; Foto Rumah minimal 3 Ibr dari depan dan samping kiri dan kanan rumah; Jumlah Bantuan sebesar Rp. 15.000.000,-

f. Setelah pengajuan diterima, akan dilakukan verifikasi kesesuaian kriteria dan persyaratan calon penerima bantuan

\section{Inovasi Pelayanan Santunan Kematian}


Bagi warga Kudus berhak untuk memperoleh santunan kematian sampai dengan satu juta rupiah, dengan ketentuan dan persyaratan-persyaratan sebagai berikut :

a. Mengisi surat Permohonan santunan kematian atau formulir yang disamakan ditujukan kepada Bupati Kudus

b. Foto copy KTP dan KK yang masih berlaku milik penduduk yang meninggal dunia yang diketahui oleh Ketua RT dan RW setempat.

c. Foto copy Surat Keterangan Kematian dari Desa / Lurah dilegalisir

d. Surat Keterangan ahli waris dari Kepala Desa / Lurah dilampiri :

e. $\quad$ Foto copy KTP dan KK ahli waris dilegalisir Ketua RT dan RW setempat.

f. Surat Keterangan Tidak Mampu (SKTM) dari Kepala Desa / Lurah setempat yang menyatakan bahwa penduduk yang meninggal dunia tidak mampu atau Penerima atau anggota keluarga dari penerima Bantuan Langsung Tunai (BLT) atau Jaminan Kesehatan Masyarakat/ Jaminan Kesehatan Daerah atau Penerima Program Keluarga Harapan.

g. Bagi penduduk yang meninggal dunia disebabkan karena KECELAKAAN atau sebab-sebab lain yang bersifat luar biasa dilampiri Surat Keterangan Kematian karena kecelakaan dari dokter rumah sakit atau Puskesmas dan / atau surat Keterangan dari Kepolisian.

h. Dalam hal ahli waris lebih dari 1 (satu) orang, maka ditunjuk salah satu ahli waris yang mewakili dan mendapat kuasa dari seluruh ahli waris yang lainnya dan dituangkan dalam Surat Kuasa bermeterai cukup.

i. Surat Kuasa dari seluruh ahli waris kepada salah satu ahli waris dilampirkan sebagai tambahan persyaratan pengajuan permohonan bantuan uang duka.

j. Surat permohonan dari ahli waris diteliti kebenarannya atau keabsahannya (diverifikasi) oleh Kepala Desa / Lurah, dibuat rangkap 3 (tiga),

k. Pendaftaran permohonan bantuan santunan kematian paling lambat 7 (tujuh) hari kerja dihitung sejak meninggal, sudah harus diterima oleh 
Petugas Pendaftaran bantuan Santunan Kematian Dinas Sosial, Tenaga Kerja dan Transmigrasi Kabupaten Kudus.

\section{PEMBAHASAN HASIL PENELITIAN}

Tenaga SDM yang menangani permohonan kartu Pencari Kerja atau Kartu Kuning di Dinsosnakertrans Kabupaten kudus, masih sangat terbatas, masih kurang dari cukup. Apa yang terjadi adalah sudah banyak tenaga yang pensiun, tapi tidak segera digantikan dengan pegawai baru. Meskipun demikian, hal ini sangat terbantu dengan adanya tenaga kontrak yang diberdayakan untuk menangani pekerjaan-pekerjaan bidang ini. Selain itu dengan adanya sistem online juga mempermudah bagi para pemohon Kartu Pencari Kerja dalam proses pengurusannya.

Mereka yang sedang mengurus Kartu Kuning adalah mereka yang terdaftar di Dinsosnakertrans sebagai tenaga kerja yang sedang mencari peluang kerja di bursa atau pasar kerja yang disebut sebagai pencari kerja. Data pencari kerja di Kabupaten Kudus selama 7 tahun terakhir menunjukkan angka penurunan yang signifikan. Gejala penurunan ini tentunya menggembirakan karena berarti bahwa tenaga kerja yang ada sudah terserap dalam pasar kerja. Jumlah pencari kerja yang semula berjumlah 11.645 orang pada tahun 2008, pada tahun-tahun terahir yaitu tahun 2014 turun drastis menjadi 5.526 orang. Hal yang menarik adalah bahwa sepanjang tahun ternyata pencari kerja wanita selalu lebih banyak dibanding dengan pencari kerja laki-laki.

\section{Inovasi Pelayanan Bedah Rumah}

Rumah merupakan tempat tinggal yang utama bagi setiap keluarga inti. Rumah menjadi tempat berlindung dari guyuran air hujan dan panas teriknya matahari. Dari rumah itu pulalah akan terbangun sebuah keluarga yang saling mencintai antara antara anak dengan orang tua dan sebaliknya. Dari rumah itu pulalah berkembang kepribadian anak menuju remaja dan dewasa. Namun apa yang terjadi seringkali kita lihat bahwa kondisi rumah masih jauh dari layak sebagai tempat hunian. 
Pemerintah Kudus sebagai stakeholder yang peduli kepada rakyatnya tentunya tidak tinggal diam melihat kondisi rumah warganya yang jauh dari layak huni. Untuk itu melalui program bantuan bedah rumah bagi penduduk dan warga Kudus yang kurang mampu memiliki kesempatan untuk memperoleh pelayanan berupa bedah rumah dengan persyaratan yang sudah diatur dalam pelaksanaannya.

Beberapa kriteria dan persyaratan pengajuan usulan / permohonan Bansos Rehabilitasi Sosial Daerah Kumuh untuk Program Inovasi Pelayanan Bedah Rumah di Kabupaten Kudus antara lain bahwa keluarga yang berhak adalah keluarga yang kondisi rumahnya dan lingkungannya tidak memenuhi persyaratan yang layak untuk tempat tinggal, baik secara fisik, kesehatan maupun sosial. Hal ini dibuktikan dengan luas' lantai yang sangat terbatas, sumber air tidak sehat, tidak punya akses MCK, bahan bangunan tidak permanen, tidak memiliki pencahayaan matahari dan ventilasi udara dan sebagainya. Setelah mereka mengajukan proposal sesuai dengan ketentuan dan persyaratan-persyaratan yang dibutuhkan akan dilakukan verifikasi kelayakannya dalam menerima bantuan. Jumlah bantuan yang diterima sebesar Rp. 15.000.000,-

Political will dan niat baik dari Pemerintah Kudus dalam membantu warganya ini seringkali menghadapi kendala dengan persyaratan-persyaratan administratif yang dibutuhkan agar bantuan bedah rumah ini bisa cair. Warga miskin yang kadang belum sadar akan arti pentingnya persyaratan birokratis ini seringkali terkendala belum lengkapnya persyaratan-persyaratan tersebut. Hal inilah yang seringkali menyebabkan mereka terpaksa harus tertunda untuk memperoleh hak bantuan tersebut. 


\section{Inovasi Pelayanan Santunan Kematian}

Warga Kudus yang meninggal dalam kondisi normal akan mendapat santunan sejumlah Rp 1.000.000,- (satu juta rupiah), sedangkan warga yang meninggal karena kecelakaan bisa memperoleh santunan sampai mencapai 2.500.000,- tentunya dengan melengkapi persyaratan2 tertentu, seperti KTP Kudus, Surat Keterangan Tidak Mampu dari Desa. Kemudian bagi mereka yang meninggal karena kecelakaan ahli warisnya berhak untuk memperoleh santunan lebih banyak yakni sampai mencapai maksimal 2,5 juta rupiah tentunya dengan melengkapi surat keterangan kecelakaan dari pihak kepolisian atau Surat Keterangan Kematian karena kecelakaan dari dokter rumah sakit atau Puskesmas.

Inovasi pelayanan santunan kematian di Kabupaten Kudus ini memang sangat dirasakan manfaatnya untuk keperluan pengurusan pemakaman bagi keluarga yang meninggal, hanya saja manfaat itu akan menjadi berkurang karena pada umumnya santunan ini diterima jauh hari setelah saat pemakaman itu terjadi.

\section{PENUTUP}

\section{Kesimpulan}

Inovasi Pelayanan Publik di Dinsosnakertrans Kabupaten Kudus sudah dilakukan dengan memberikan kesempatan pelayanan Kartu Kuning melalui online. Bantuan Sosial Bedah Rumah seringkali masih mengalami kendala karena belum lengkapnya persayaratan-persyaratan yang dibutuhkan untuk pengurusan bantuan tersebut. Bantuan Sosial Santunan Kematian masih terkendala waktu yang cukup lama untuk menurunkan bantuan tersebut karena prosedur pencairannya yang cukup panjang

\section{Saran}

Perlu adanya penambahan pegawai baru untuk mengurangi beban kerja yang terlalu banyak bagi pegawai yang telah ada. Persyaratan-persyaratan yang diperlukan untuk memperoleh bantuan sosial santunan kematian dan bedah 
rumah agar tidak diberlakukan secara kaku. Bantuan sosial santunan kematian hendaknya diberikan tidak terlalu lama dari waktu terjadinya kematian tersebut

\section{DAFTAR PUSTAKA}

BPS Kabupaten Kudus, Profil Kudus dalam Angka 2013/2014

Caiden, Gerald E, 1991, Administrative Reform Comes Of Age, Walter de Gruyer, New York

Dwiyanto, Agus,2002, Reformasi Birokrasi Publik di Indonesia, Pusat Studi Kependudukan dan Kebijakan Universitas Gadjag Mada, Yogyakarta

Denhardt, Janet V. dan Robert B. Denhardt. 2003. The New Public Service: Serving, not Steering. Armonk, New York: M.E Sharpe.

Denhardt, Robert B. dan Janet V. Denhardt. 2000. "The New Public Service: Service Rather than Steering". Public Administration Review 2011, Mengembalikan Kepercayaan Publik Melalui Reformasi Birokrasi, Gramedia, Jakarta

Effendi, Sofian, 2010, Reformasi Tata Kepemerintahan : Menyiapkan Aparatur Negara Untuk Mendukung Demokratisasi Politik dan Ekonomi Terbuka, Gadjah Mada University Press, Yogyakarta.

Ferlie, Erwan,2009, Hand Book of Public Management, Oxford, America

McLaughlin, Kate (ed), 2002, New Public Management : Current Trends and Future Prospects, Routledge, London

Hidayat, Misbach L, 2007, Reformasi Administrasi Kajian Komparatif Pemerintahan Tiga Presiden, Ikrar Mandiriabadi, Jakarta

Nasucha,Chaizi, 2004, Reformasi Administrasi Publik Teori dan Praktik, Grasindo, Jakarta

Pramusinto, Agus (ed), 2009, Reformasi Birokrasi, Kepemimpinan dan Pelayanan Publik : Kajian Tentang Pelaksanaan Otonomi Daerah Di Indonesia, Gava Media,Yogyakarta

Sedarmayanti, 2009, Reformasi Administrasi Publik, Reformasi Birokrasi, dan Kepemimpinan Masa Depan, Refika Aditama, Bandung 
Wibawa, Samodra (ed),2005, Reformasi Administrasi: Bunga Rampai Pemikiran Administrasi Negara/Publik, Gava Media,Yogyakarta

Zhijian, Zhang (ed), 1992, Administrative Reform Towards Promoting Productivity In Bureaucratic Performance, EROPA, Philippines

Peraturan Presiden RI Nomor: 81 Tahun 2010 Tentang Grand Design Reformasi Birokrasi 2010-2025

Peraturan Menpan dan Reformasi Birokrasi Nomor: 20 Tahun 2010 Tentang Road Map Reformasi Birokrasi 2010 - 2014

Keputusan Menpan No. 63/Kep/M.PAN/7/2003 tentang Pedoman Penyelenggaraan Pelayanan Publik

Peraturan Kepala BPN RI Nomor 18 Tahun 2009 tentang LARASITA (Layanan Rakyat Sertipikat Tanah)

Rencana Strategis Badan Pertanahan Nasional Republik Indonesia Tahun 20102014

Permenpan No 38 Tahun 2012 tentang Pedoman Penilaian Kinerja Pelayanan Publik

Undang Undang No 29 Tahun 2009 tentang Pelayanan Publik. 